\title{
"JENTON TURUN JENTON" LEADERSHIP OF TUMENGGUNG NGGRIP ON COMMUNITY ORANG RIMBA IN KEDUNDUNG MUDA, BUKIT DUABELAS NATIONAL PARK, JAMBI, INDONESIA
}

\author{
Sipin Putra \\ Anthropology, Universitas Indonesia, Depok, Indonesia \\ sipin.putra@gmail.com
}

\begin{abstract}
This study aims to describe Tumenggung Nggrip on Community Orang Rimba in Bukit Duabelas National Park. Political leadership can be analyzed from the Tumenggung Nggrip kinship system in this community. Custom rules "Jenton Turun Jenton" justify the political leadership in community-based on lineage by the previous leader. Politically Tumenggung Nggrip is the benefit of having a father who was to be Tumenggung. Tumenggung required to have some expertise prominent than the other. Ability to lead and understanding of custom that has been passed on by parents. Tumenggung Nggrip is superior compared with other individuals. Leadership held by close relatives of the Tumenggung. The kinship system in political leadership is able to confirm the position of Tumenggung as a respected. It has the power of access to economic resources, social and relationship with outsiders. Political level as a community can be analyzed as a form of democracy, but in practice, it tends to be influenced by the attitude of a leader in custom enforcement. Social system and political organization Orang Rimba is built on the concept of family, marriage, and kinship system.
\end{abstract}

Keywords: Tumenggung, Kinship, Orang Rimba

DOI: $10.33541 /$ sp.v20i1.1440

Sociae Polites : Majalah IImiah Sosial Politik

Faculty of Social and Political Science, Universitas Kristen Indonesia

ISSN 1410-3745 print/ ISSN 2620-4975 online

Volume 20, Number 1 (January - June 2019)

Pages 20-34 


\section{Background}

The politics of Tumenggung Nggrip leadership in the Orang Rimba indigenous community seen its existence in Bukit Duabelas National Park (TNBD) is the basis of this paper. The Orang Rimba community is flexible in dealing with changes that occur in the TNBD. They also adopted a new culture that came from the Light, so they remained to survive as indigenous peoples living in forest areas. The social dynamics culture in this community ensued. The Orang Rimba Community still exists because of this, the leader of his group; Tumenggung Nggrip can carry out leadership and make a policy regarding the survival of the Jungle People for now and in the future.

A Tumenggung is in charge of leading the Orang Rimba in his day-to-day cart according to customary law. Political expertise needed for a Tumenggung to be able to manage managerial groups and relations with outsiders. The form of leadership of a Tumenggung is increasingly visible when resolving problems in his cart. Skill in resolving cases fairly so members of his community can respect him. Disobedience, even disobedience, the exodus to move to another group, is a form of disappointment, poor political decisions, and policies. Rupture of groups in each the cart is not only caused to avoid conflict but the availability of resources also population explosion. Group or group defined as several people who have a pattern of interaction that is organized and occurs repeatedly or deeply. Another understanding of each group of people who have a mutual and mutual awareness interact with each other.

The group then split into smaller groups. Leadership This new group led to a competition of several Orang Rimba men for becoming Tumenggung. But in the end, the customary rule "Jenton turun Jenton" is still strongly obeyed by Orang Rimba in the selection of Tumenggung. The kinship from Tumenggung had previously provided a golden opportunity for their sons to carry on the politics of jungle leadership. Tumenggung heirs from the Tumenggung kinship previously responsible for accommodating the lives of Orang Rimba in TNBD that still exist while changing forest conditions.

\subsection{Research Problem}

Studies on leadership forms in indigenous communities such as the Orang Rimba essential to do in seeing their existence in certain regions. Leadership Tumenggung Nggrip in the Orang Rimba indigenous community in TNBD can help us in understanding and analyzing the presence of this community. Research on how traditional community leadership is still essential to do. The theme of this research can explain the existence of a society in facing social-cultural change.

The form of administration of Tumenggung Nggrip in the Orang Rimba Community can see with a historical analysis approach. Tumenggung Nggrip comes from a group of Orang Rimba from another area (Makekal Hulu) then moved to Kedundung Muda. Together with the leadership of the device, he uses a kinship. Sister of Tumenggung Nggrip is believed to be the traditional elder and trusted representative of Tumenggung to treat sick community members. His sister-in-law, Mangku Besemen as well Mangku adat, is supposed to lead traditional ceremonies and hearings.

The Tumenggung Nggrip leadership has a long-standing selection mechanism. Tumenggung Nggrip became a leader through a selection mechanism from candidates who met the criteria. Then held a ceremony for the selection and appointment of a 
Tumenggung. "Jenton turun Jenton became an adat rule of the Orang Rimba in the form of its leadership system. Tumenggung Nggrip's parents came from a group in Makekal Hulu. His father, Tengganai Ngembar, previously a Tumenggung. Tumenggung Nggrip replaced his father's leadership position. Nggrip then moved from Makekal Hulu to Kedundung Muda. Tumenggung Nggrip politically benefited from having a father who is a former Tumenggung. The late Tengganai Ngembar is an honorable person in his community. In the Kedundung Muda group, his siblings became traditional elders so that Nggrip can easily lead and accommodate its citizens in daily life. Tumenggung Nggrip is also able to speak Indonesian, hunt, garden and can have good relations with the Malay community and transmigrants around the TNBD.

\subsection{Objective and Purpose}

This paper explains the leadership form of Tumenggung Nggrip in the Orang Rimba Community in terms of its kinship. Political life in the Orang Rimba group led by Tumenggung Nggrip is exciting to study because individuals who lead a community have an essential role in the existence of the city and relationships that occur with outsiders. The purpose of Tumenggung Nggrip in leading and making decisions regarding customary rules and fines for members of his community is significant in preserving traditional standards that have been in place for a long time. This local politics can analyze as a form of communal life.

Still, the practice tends to be influenced by attitudes of a leader, law enforcement, and also adat in this community. Another problem arises where their existence in the middle of the forest is starting to change. The role of Tumenggung Nggrip is evident in the face of changes in the woods of Bukit Duabelas National Park. Tumenggung Nggrip's leadership to the Orang Rimba Community was able to be a common thread in seeing the life of the community. They can live together in the face of changing forest functions today.

\section{Literature Review}

The social development process for the Orang Rimba Community carried out by the government has not been optimal. There are several obstacles, namely the incompatibility of the program with the socio-cultural conditions of the Orang Rimba community. It is also related to strategic plans that do not pay attention to the potential and existence of the city. For example, the ex-situ housing development program is contrary to Melangun culture. Orang Rimba, so that the program is not running optimally. The house built was left by the Orang Rimba, who went to Build because a group member died. The Orang Rimba social and political organization built on the concepts of family, marital relations, and kinship. "Rombong formed as an area with the division of power based on the flow of the river is a picture of intertwined family relations of the Orang Rimba. Individuals united by marriage then produces a kinship.

This kinship has implications for the power and political role of its members. As written by Ted. C Lewellen inside Political Anthropology, explains that traditional communities are still simple in the form of bands. They tend to use kinship for their social and political life. The amount in one group (bands) is relatively small. Tumenggung quickly leads the community because there are around 350 of them. Nggrip prioritizes political abilities and skills, so that customary rules are maintained and obeyed by all 
individuals. Individual stratification in groups becomes a dominant feature. The need to be led and lead requires the existence of customary law that can guarantee the certainty of daily socio-political life. Therefore, a Tumenggung Nggrip, along with their representatives and conquerors who incidentally still have a close kinship to establish the customary rule "Jenton turun Jenton." This rule is reflected in the Tumenggung leadership activities so far. Leadership activities are not activities that can be carried out by only one person. They can form alliances to help the businesses that will be carrying out. The scope of political activities, where politics defined as an effort to achieve specific goals, now more interpreted as activities related to leadership and power.

The Cognatic System, written by Jeremy H. Kemp, explains the kinship that underlies a family in Southeast Asia. The kinship system is non-unilineal in which the individual's affiliation with his relatives is related to his ego through both parents - the kinship traced through his mother or father. Communities with kinship groups are much more cognatic compared with the unilineal kin group. This kinship system generally located in Polynesia, Indonesia, Malaysia, and the Philippines. This kinship system has no clear rules. Even some group's relatives of the cognatic system show a pattern that leads to shelter based on the existence of their land for regeneration and sources of livelihood.

The Orang Rimba political system is flexible in facing the socio-cultural changes of its community. Tumenggung Nggrip adopted these changes so that they remained in the forest. The internal dynamics of this community emerged as a reaction to the form of leadership of Tumenggung Nggrip. Leadership dynamics Nriprip is done so that it still exists in the face of environmental changes. Now the Orang Rimba in the Tumenggung Nggrip group can live amid changes in the TNBD environment. It is inseparable from the leadership of Nggrip in making decisions and policies daily. Research starts from a theoretical perspective with a conceptual framework for interpreting field findings. The theoretical perspective can determine the focus of the study (in Patton, Michael Quinnn, 2002. Qualitative Research \& Evaluation Methods. Sage Publication, London). A theory becomes critical because it not only studies and understands society but also criticizes and makes changes in society. In summary, in symbolic anthropology, it is based on the concept that an organization has a system of shared symbols and meanings called culture and aims at studying and researching a process through which humans give sense to the world and their actions (contained in Saifuddin, AF 2005. Contemporary Anthropology: A Critical Introduction to the Paradigm. Jakarta: Kencana. Pages 296, 395).

The ethnographic method wants to explain the phenomena behind the reality that looks at the field. Ethnography can criticize the status quo and challenge the taken-forgranted assumption, which appears to underlie the operation of social power and control in the Orang Rimba community. Ethnographic methods are essential when a researcher is or "on the ground of others" and can face social conditions that are the starting point for research.

\section{Data Analysis}

The analysis conducted in explaining the form of leadership of Tumenggung Nggrip in the Orang Rimba indigenous community. The scope includes the administration and political life of Tumenggung Nggrip in daily activities. Activities or events that involve actions in the processual approach of focusing studies. On occasions that are related to one another on an ongoing basis can help anthropologists in studying a process 
(Winarto, 1999: 26). From Tumenggung Nggrip of politics, economics, and socio-culture became material for analyzing forms of leadership in the Orang Rimba community. The Orang Rimba community in Kedundung Muda, the Tumenggung Nggrip group, is the focus of this article.

\subsection{Rombong Tumenggung Nggrip}

Romberg in the Orang Rimba community group is as in the concept of the bands described by Ted C. Lewellen, wherein the bands characterized as a small group of hundreds of members. This group is also usually formed from a nuclear family.

The division of work is still simple, for example, based on sex and age. These groups or bands formed with ties of customs, traditions, habits, values, and symbols in everyday life. The type of leadership is informal and situational, in which a tribal chief (Tumenggung) can decide an adat meeting. The Jungle People give the title of a leader with Tumenggung. The concept of Tumenggung is cultural relics from the royal era, especially the Kingdom of Srivijaya. The kinship system is bilateral, where the kinship relationship influences the composition of the group - the social network formed by marital relations. "Rombong" also created from the kinship system of the existing family.

Economic ties formed from the interchange of individuals in groups. They even

still use the method of bartering and sharing from hunting results to fulfill their daily needs. Economic activity with this exchange system can make the relationship between individuals in groups (bands) is getting tighter. Property ownership as private property is still small because it powerfully formed from kinship to each of its members. Tumenggung still holds political activities, but the ability to lead and politics is owned by individuals who have more authority and expertise than other individuals. Life in a cart does not apply formal law, and social control implemented with customary law that is applicable and communal. Their religious system is still developing in line with the influence of life outside the forest because they still worship gods and nature. Tumenggung Nggrip Rombong in Kedundung Muda is an Orang Rimba band in the TNBD area.

\subsection{Composition of The Jungle Rombong Tumenggung Nggrip}

The Jungle People live in groups according to their Tumenggung leadership area. Furthermore, it divided into sub-groups according to the bedroom or residential areas. 
Tabel 1. Structure of the Orang Rimba Rombong Kedundung Muda

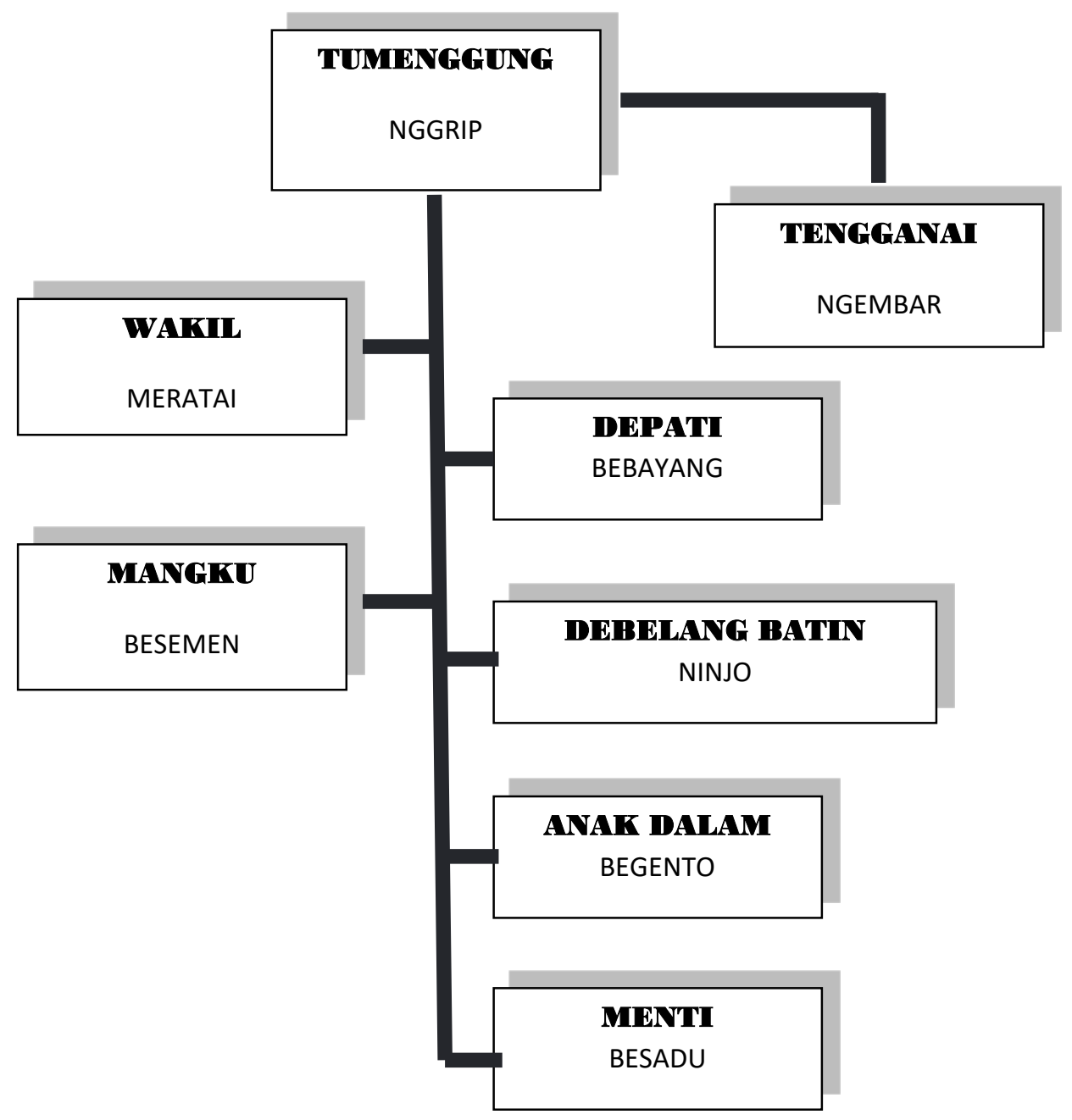

Sumber: Warsi, Zainuddin, 2009

Tumenggung Nggrip region covers the boundary of the Thundering or River Lembing towards Kembang Bungo and Air Behan with the central government in Kedundung Muda. Learn from experience by choosing a close relative to be a rank uniting group members who tend to split. This method is a strategy to control as many resources as possible and to distribute more to the rank of people who are also close relatives. Besides, with the many relatives, the administrative support capacity for Tumenggung will be even higher as the chart above displays the leadership structure of Tumenggung Nggrip together with his relatives.

\subsection{Distribution of the Orang Rimba di Kedundung Muda}

The distribution of the Orang Rimba, according to the Tumenggung Nggrip area corresponds to the territorial boundary, as shown in table 2 .

Tabel 2. Distribution of Orang Rimba 


\begin{tabular}{|c|c|c|c|}
\hline NO. & LOCATION & SUB-GROUP & NOTES \\
\hline 1. & Kedundung Muda & $\begin{array}{ll}\text { 1. } & \text { Tumenggung Nggrip } \\
\text { 2. } & \text { Mangku Besemen } \\
\text { 3. } & \text { Gemambun } \\
\text { 4. } & \text { Mulung } \\
\text { 5. } & \text { Meluring } \\
\text { 6. } & \text { Nyingkap (her wife is dead) }\end{array}$ & 6 Pesaken (Family Head) \\
\hline 2. & Tanah Kepayong & 1. Njalo & 1 Pesaken \\
\hline 3. & Pisang Krayak & 1. Prabung & 1 Pesaken \\
\hline 4. & Air Behan & $\begin{array}{ll}\text { 1. } & \text { Setapak } \\
\text { 2. } & \text { Nyatang } \\
\text { 3. } & \text { Bekulam } \\
\text { 4. } & \text { Sedih } \\
\text { 5. } & \text { Meratai }\end{array}$ & 5 Pesaken \\
\hline 5. & Muara Air Behan & $\begin{array}{ll}\text { 1. } & \text { Besadu } \\
\text { 2. } & \text { Ngandun } \\
\text { 3. } & \text { Pelanggar } \\
\text { 4. } & \text { Begento } \\
\text { 5. } & \text { Nyejuk } \\
\text { 6. } & \text { Sicikat Lundang } \\
\text { 7. } & \text { Cangking } \\
\text { 8. } & \text { Neliti } \\
\text { 9. } & \text { Ngampun }\end{array}$ & 9 Pesaken \\
\hline 6. & Suban Gemuruh & $\begin{array}{ll}\text { 1. } & \text { Ngayat } \\
\text { 2. } & \text { Nurai } \\
\text { 3. } & \text { Nutup } \\
\text { 4. } & \text { Meredu } \\
\text { 5. } & \text { Ngimbau } \\
\text { 6. } & \text { Pembilang }\end{array}$ & 6 Pesaken \\
\hline 7. & Sako Talun & $\begin{array}{ll}\text { 1. } & \text { Najuk } \\
\text { 2. } & \text { Besangkil } \\
\text { 3. } & \text { Melehai } \\
\text { 4. } & \text { Nyubur } \\
\text { 5. } & \text { Beramal } \\
\text { 6. } & \text { Ngeledeng } \\
\text { 7. } & \text { Ejas } \\
\text { 8. } & \text { Dobang } \\
\text { 9. } & \text { Kluhu }\end{array}$ & 9 Pesaken \\
\hline
\end{tabular}




\begin{tabular}{|c|c|c|c|}
\hline 8. & Teruyon & $\begin{array}{ll}\text { 1. } & \text { Ninjo } \\
\text { 2. } & \text { Kepia } \\
\text { 3. } & \text { Doyet } \\
\text { 4. } & \text { Prado } \\
\text { 5. } & \text { Neka } \\
\text { 6. } & \text { Jubai } \\
\text { 7. } & \text { Genap } \\
\text { 8. } & \text { Sergi (godong) } \\
\text { 9. } & \text { Mulau (duda) } \\
\text { 10. } & \text { Gaek (janda) }\end{array}$ & 10 Pesaken \\
\hline 9. & Belukar Sejelai & $\begin{array}{ll}\text { 1. } & \text { Selambai } \\
\text { 2. } & \text { Nyabal } \\
\text { 3. } & \text { Siray } \\
\text { 4. } & \text { Merbab } \\
\text { 5. } & \text { Melancar } \\
\text { 6. } & \text { Lirip } \\
\text { 7. } & \text { Bekaco } \\
\text { 8. } & \text { Uga } \\
\text { 9. } & \text { Bereban (janda) } \\
\text { 10. } & \text { Nyusup (janda) }\end{array}$ & 10 Pesaken \\
\hline 10. & Sungai Tengkuyung & $\begin{array}{l}\text { 1. Laman } \\
\text { 2. Sidun }\end{array}$ & 2 Pesaken \\
\hline 11. & SPI - SPG & $\begin{array}{ll}\text { 1. } & \text { Meriau } \\
\text { 2. } & \text { Ngelawang } \\
\text { 3. } & \text { Nganduy } \\
\text { 4. } & \text { Spendek } \\
\text { 5. } & \text { Lora } \\
\text { 6. } & \text { Budak Itam } \\
\text { 7. } & \text { Nyerak } \\
\text { 8. } & \text { Mentik }\end{array}$ & 8 Pesaken \\
\hline & & Jumlah: & 67 Pesaken \\
\hline
\end{tabular}

Source: KKI Warsi, Zainuddin, 2009

From the data above, it looks that the tendency of groups to separate themselves is very high so that there are 11 sub-groups. Some factors that make them unified and separate, include:

1. Kinship relations

The relationship between the Jungle People in the sub-group is a close relative relationship, such as a nuclear family, parents-in-law, younger siblings, son-inlaw, and parents-in-law.

2. Equality of interest

The existence of the same benefits to maintain resources, fields, Benuaron (areas of many trees that contain honey bees), shrubs, and others make this subgroup join.

3. Group characteristics 
The characteristics of the Meriau group and the Ninja group differ in terms of cultivation with groups in Kedundung Muda, Pisang "Krayak," and Tanah Kepayong. The "Krayak" Banana Group and the Kepayong Land Group are always busy with cultivation activities and seasonal crops such as tubers as a source of food and rubber as a source of income. While the "Ninja group has always moved from oil palm plantations, so has the Meriau group that has transferred from nucleus oil palm plantations (1) to the nucleus (2).

4. Distribution of resources

In terms of the spatial location of the "Benuaron, the role of the "Akakon and group rubber fields in Pisang "Krayak," Kedundung Muda, Tanah Kepayong, and Shrub Soybean are close together so that interactions occur intensively.

5. Relationship with the outside world

"Rombong" Kedundung Muda, Belukar Sejelai, Teruyon, SPG-SPI, Banana "Krayak," and Tanah Kepayong have a close relationship with Bukit Suban Village both for economic and social relations. Governance activities are only carried out by Tumenggung Nggrip, and Mangku Besemen is more intensive in attending various meetings compared to the headman or other ranking people. Tumenggung representatives, Meratai and Depati Setapak, rarely deal with outsiders.

\subsection{Kinship of the Jungle Rombong Tumenggung Nggrip}

Table 3. Kinship of Tumenggung Nggrip

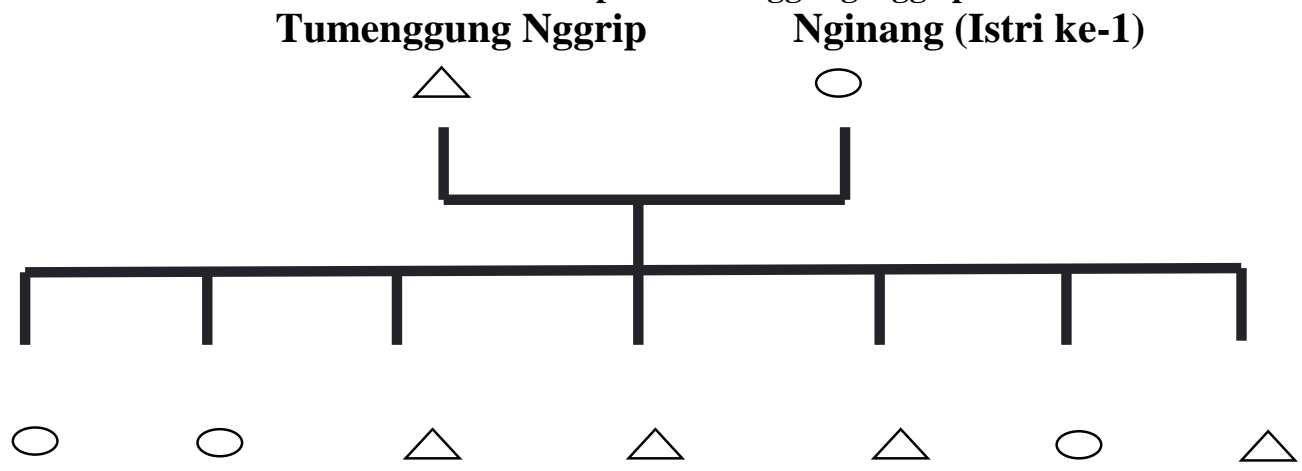

Beraden Nari Bungo Sergi Jujur Kemetan Besanggul Bekantong Suntin

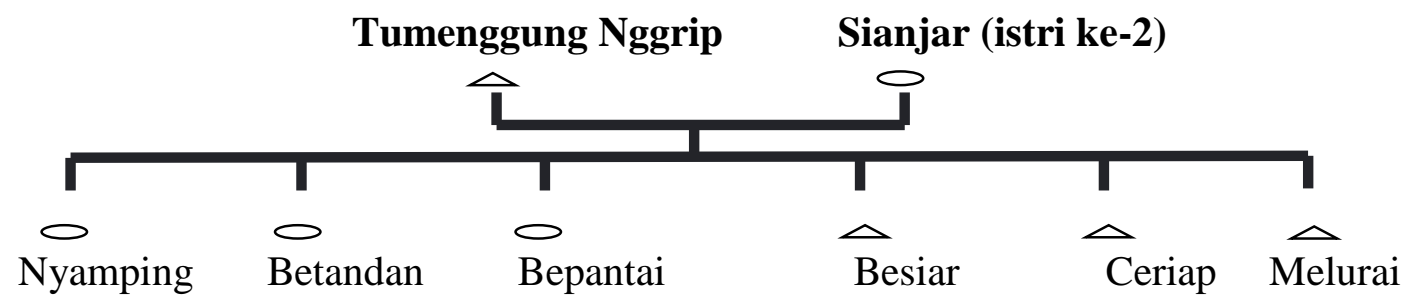

The family system and Orang Rimba social organization, beginning with the term "inheritance," interpreted as female relatives and relatives on the wife's side. These heirs have a strong and prominent position and role in their social organization. While the 
nuclear family is lacking has economic and political independence because it is very tied to its inheritance. Kinship with the matrilineal system can be a pride for the Orang Rimba. It is not the case of Orang Rimba men but members of groups who adhere to the system matrilineal. A sense of pride arises when a girl marries a person of good rank who is single, widowed, or married. The nuclear family for the Orang Rimba is called a ridge consisting of husband, wife, unmarried girls, and eligible boys (single). If a boy is an adult, then he is required to separate from his parents' house and live in a Perako house and usually located close to their fields. It is a form of independent living learning education, including foraging before she gets married. The meaning of kinship of the Jungle People socially contains reciprocal exchange relationships, Which reciprocity based on traditions and customs, and related to the individual states. Also or the gift tradition, or the cooperation tradition. The complementary aspects of kinship are helpful. Besides that, it is also the collectivity of being together.

\subsection{Meanings of Kinship Relations in the Jungle Leadership} include:

The meaning contained in the kinship relationships in the Jungle Leadership

\section{- Politically}

Kinship is political, seen by the existence of binding through the pattern of marriage in the village (under four) of their neighbors in a group or subgroup that shows an effort to maintain power. Tumenggung Nggrip is a child from the previous Tumenggung, namely Tengganai "Ngembar." So, the child replaces the position of the father following the customary rules "Jenton turun Jenton." The father passed away in 2009. Before he died, "Bepak" Ngembar served as Tengganai, an advisor to Tumenggung. The phenomenon of the former Tumenggung became Tengganai, and his son, who later replaced him, strengthened the opinion that Tengganai is a more prestigious position. Besides, a Tengganai required to understand adat issues fully. The selection of close relatives to rank people will be able to unite group members. This method is a strategy in controlling as many natural resources as possible and is distributed more to his close relatives. Also, political relations aim at kinship, maintaining the Jungle People or groups themselves (regeneration).

In Rombong Tumenggung Nggrip, it appears that the headman or a person of rank is a relative the closest. One of the critical things in the political career of Tumenggung Nggrip is a broad knowledge of customary law. The people of that rank are excellent legal experts who talk and argue. Experience and expertise often used to manipulate the law and violation cases. It is especially crucial for those who are directly involved in the process of paying traditional cloth fines. For the Orang Rimba, the size of the cloth is a fixed standard for any violations of adat. Still, bargaining by being skillful in manipulating customary or legal violations is a reference to determine the final decision. Shrewdness can be seen from the speech of straightforward language, natural language intonation, controlled emotions, facial expressions, and body movements so that one can convince others. Arena of political debate as well as testing and showing jungle people for the quality of Tumenggung or people of rank. They often call "konon ake" to drink, Tai "knawon" to "akon" as an apology before starting a conversation, or if you want to 
respond to the opinions of other actors. The other person will react in a more passionate style but aims to influence the final decision.

Table 4. Kinship of Tumenggung Nggrip

\begin{tabular}{|c|c|c|c|}
\hline No & Penghulu & Family & Relationship \\
\hline \multirow{7}{*}{1} & \multirow{7}{*}{ Tengganai Ngembar } & Tumenggung Nggrip & Anak (ke-2) \\
\hline & & Meratai & Anak (ke-1) \\
\hline & & Bebayang & Menantu(Mengkanak) \\
\hline & & Besemen & Menantu \\
\hline & & Setapak & Keponakan \\
\hline & & Begento & Menantu \\
\hline & & Besadu & Menantu (Mengkanak) \\
\hline \multirow{6}{*}{2} & \multirow{6}{*}{ Tumenggung Nggrip } & Meratai & Saudara kandung \\
\hline & & Bebayang & Ipar \\
\hline & & Besemen & Ipar - Besan \\
\hline & & Setapak & Menantu (Mengkanak) \\
\hline & & Begento & Kakak beradik \\
\hline & & Besadu & Kakak beradik \\
\hline \multirow{5}{*}{3} & \multirow{5}{*}{ Meratai } & Bebayang & Ipar-Besan \\
\hline & & Besemen & Menantu \\
\hline & & Setapak & Kakak beradik \\
\hline & & Begento & Kakak beradik \\
\hline & & Besadu & Kakak beradik \\
\hline \multirow{4}{*}{4} & \multirow{4}{*}{ Bebayang } & Besemen & (orang tua berdulur) \\
\hline & & Setapak & Ipar-Besan \\
\hline & & Begento & Ipar \\
\hline & & Besadu & Ipar-Besan \\
\hline \multirow{3}{*}{5} & \multirow{3}{*}{ Besemen } & Setapak & Kakak beradik \\
\hline & & Begento & Kakak beradik \\
\hline & & Besadu & Ipar-Besan \\
\hline \multirow{2}{*}{6} & \multirow{2}{*}{ Setapak } & Begento & Urang Hubanon \\
\hline & & Besadu & Mengkanak \\
\hline 7 & $\begin{array}{c}\text { Begento } \\
\text { (Bepak Ngeliling) }\end{array}$ & Besadu & Mengkanak \\
\hline
\end{tabular}

\section{- $\quad$ Economically}


Economically it can be seen from the distribution of food or louq and sensitive assets. Several meanings of the Orang Rimba kinship can be seen economically through marriage ties through the Semendo tradition. Semendo tradition produces a binding and bound relationship such as a son-in-law, and the mother-in-law relationship has implications for economic goals. The inheritance of brother-in-law becomes a motivation for his wife's family, especially in-laws and in-laws. Kinship structure explains the wife is the property husband for being paid with a dowry. The husband belongs to the Dulurdulur from his wife.

The position as a ruler also gives economic meaning to the Orang Rimba. There are no eternal and formal rewards for excellent skills services to decide or settle a case in the Orang Rimba community. The salaries "salary" is generally obtained from the distribution of the number of fines won by him. The amount must divide according to the agreement of fellow principals who have contributed to the settlement of adat cases. Fines are penalties for violations that occur-fines imposed in the form of cloth. Fabric is a valuable item that has broad benefits. The role of fines is huge, namely maintaining various customary rules.

\section{- $\quad$ Socially}

The family relationship of the Jungle People can be seen socially in terms of service and service. The service and service referred to is the obligation and right to a binding relationship based on finally, consanguinity and sibling cousin between them. Devotion and service are evident in the relationship between son-in-law and Mentuha, also between Nakanmamok. Examples of dedication that contain the meaning of the form of obedience, responsibility, and right of "Nakan" to Mamok or vice versa are Mamok obliged to visit Makan, give advice or call Belabe (Becakopcakop and give information which all have customary arrangements). "Nakano" forced to serve and obey "Mamak." The relationship between "Mamok" and Nakan is Powerful because it is often called subordinates. "Mamak" is mighty over "Nakan" and lived together since childhood. An ego child can live and live in Mamok's house indefinitely so that the position of the child with "Nakan" (subordinates) is almost invisible from the outside.

\section{- Culturally}

Marriage is one of the things that can bind and strengthen the cultural relations of the Jungle People. Also, there is a growing value, namely respect for the leader of the rank of their group. The tendency to polygamy among Orang Rimba, especially the prince or the status of the person, is the tendency in Rombong Tumenggung Nggrip.

\section{Study Interpretation of the Relationship of the Jungle People}

Based on the results of studies on kinship systems and leadership politics, it concluded that the relationships, methods, and kinship patterns in the Orang Rimba in TNBD reflected in egalitarian language. The Jungle People have a considerable distance of power. Tumenggung Nggrip plays a dominant role in the organization of community life. It appears that men play a dominant position, but women can be the reason for a man obtaining "recognition" as a prince because of marital relations. So the son of a Tumenggung is expected to be able to inherit his father's responsibility as in the 
customary rules of JentonJenton. Tumenggung Nggrip demonstrates a democratic attitude in making usual fines decisions for violating Orang Rimba. There are custom verses such as "Bonner Pemulu Pecat' law, wrong "law Pemulu Pecat," "Hopi Tehukum Pemat Pecan." But there is still an opportunity for Tumenggung Nggrip to interpret the customary law of the jungle as desired by his personality. This results in leadership can also be less democratic.

According to Christopher Boehm (in the Bands Society), the hypothesis of "limitation" of Tumenggung authority said to be a pattern of reverse dominance so that a Tumenggung does not enforce actions. It makes a Tumenggung not have the strength to act according to his wishes. The reality on the ground, opaqueness, and unclear customary law allows Nggrip to interpret and modify customary law by the conditions on the ground. a Tumenggung characterized by the amount of wealth or strands of cloth he possesses from the results of the adat session he leads. Tumenggung leadership politics in Orang Rimba cannot see in clear rules of political succession. Political succession can occur when there is death, age, and severe cases for a Tumenggung. At this stage of the sequence, there will be a little shake because there will be competition from several relatives of Tumenggung men who are interested in changing the position.

The basic principles of the "Orang Rimba" social arrangements are The nature of the Lord's shrine. The people shrine of the prince. Also the home of the church of Tengganai. And also chant of the shrine brother to the church of the elder brother". It means that whatever nature conditions are, at the will of God, the people obey the authority, home affairs must follow Tengganai, the wife must be obedient to her husband, and sister must be obedient to the older brother. If, for no apparent reason, they violate the fine imposed. It means that the compliance demanded is not absolute. But if the reasons can be accepted, then defiance is left and is considered as something positive. If good, then any decision must be obeyed absolutely. If the decision is wrong, then it may not be followed. The rules are like the saying 'Rajo is just, Rajo worshiped, Rajo is wrong, Rajo has refuted' Disclaimer against Tumenggung became a form of protest. The Tumenggung position is hereditary. Only the previous Tumenggung descendants were considered the fittest to hold the position. 


\section{BIBLIOGRAPHY}

\section{Books}

Cresswell, John W. (2003). Research Design. Qualitative, Quantitative, and Mixed Methods Approaches. London, New Delhi: Sage Publications.

Denzin, Norman K dan Lincoln, Yvonna S. (2000). Handbook of Qualitative Research. California, USA: Sage Publication, Inc.

Handini, Retno. (2005). Foraging yang memudar, Suku anak dalam di tengah perubahan; Yogyakarta, Galang Press.

Kemp, Jeremy H. (1978).Cognatic descent and the generation of social Stratification in Southeast Asia.no:1, Leiden, 63-83.

Lewellen, Ted C. (1983). Political Anthropology an Introduction. Massachusetts: Bergin \& Garvey Publishers, Inc.

Manurung, Butet. (2007). Sokola Rimba: Pengalaman Belajar Bersama Orang Rimba. Yogyakarta: Insist Press.

Rudyansjah, Tony. (2009). Kekuasaan, Sejarah dan Tindakan. Jakarta: Rajawali Pers.

Sandbukt, Oyvind dan Warsi. (1998). Orang Rimba: Penilaian Kebutuhan Bagi pembangunan dan Keselamatan Sumber daya, Laporan untuk Bank Dunia. Jambi:Warsi.

Saifuddin, Achmad Fedyani. (2005). Antropologi Kontemporer. Suatu Pengantar Kritis Mengenai Paradigma. Jakarta: Prenada Media Group.

Suparlan, Parsudi. (2004). Hubungan Antar Suku bangsa. Jakarta: YPKIK

\section{Journals}

Budi Utomo, Agus. (2001). "Taman Nasional Bukit 12, Taman Nasional di Tengah Propinsi Jambi”. Alam Sumatra dan Pembangunan Edisi 1/1/200: hal 4-6

Depsos RI. (1998). Masyarakat Terasing Suku Anak Dalam dan Dusun Solea Dan Melinai. Direktorat Bina Masyarakat Terasing, Jakarta.

Dian Prihatini. (2007). Makalah "Kebudayaan Suku Anak Dalam”. Fakultas Ilmu Sosial dan Ekonomi. Universitas Negeri Yogyakarta, Yogyakarta.

Juandaru, Bintoro. (2001). Nasib Bukit 12 setelah Berstatus Taman Nasional, Tekanan dan Ancaman (sudah) di Ambang Pintu. Alam Sumatra dan Pembangunan, Edisi 1/1/2001: hal.16-17

KKI Warsi.(2001). Buletin Alam Sumatera: Dituduh Gila Karena Ungkap Kolusi; wawancara dengan Alberto Lucida, Jambi.

KKI Warsi. (2002). Potret Persoalan Taman Nasional Bukit Duabelas Bagian Utara dan Barat, Jambi.

KKI Warsi. (2003). Buletin Alam Sumatera:Toke,dewa penolong bagi masyarakat desa Padang Kelapo.

KKI Warsi. (2003). Makalah KKI Warsi dalam Seminar Fleght-SP Partisipasi

Komunitas Lokal dalam Pengamanan TNBD dan Pemanfaatan Lahan Terlantar, Jambi.

KKI Warsi. (2003). Studi Kebijakan Pembangunan;Pemanfaataan Ruang dan Sumber Daya Alam. KKI Warsi. Lembaga Penelitian Universitas Jambi dan Bappeda Kabupaten Batanghari. Jambi 
KKI Warsi dan BirdLife. (2006). Refleksi Pengelolaan Hutan Jambi. Jambi

Muchlas, Munawir. (1975). Sedikit Tentang Kehidupan Suku Anak Dalam (Orang

Kubu)di Provinsi Jambi, Kanwil Depsos Provinsi Jambi, Jambi.

Saudagar, Fachruddin. (1993). Kebudayaan Melangun Masyarakat Suku Anak Dalam.

Makalah dalam Seminar Meningkatkan Harkat dan Martabat Suku Anak Dalam di daerah Jambi pada 6 Desember 1993. Jambi. Universitas Jambi.

Sandbukt, Oyvind dan Warsi.(1998). Orang Rimba: Penilaian Kebutuhan Bagi Pembangunan dan Keselamatan Sumber daya, Laporan untuk Bank Dunia. Jambi:Warsi.

Sandbukt, Oyvind. (2001).Orang Rimba Tempo Doeloe, Baduy Dalam-nya Sumatera. Buletin Alam Sumatera Volume 1 Januari 2001, WARSI. 2001.

Semiarto Aji Purwanto. (2005).Taman Nasional, Hak-hak Masyarakat Setempat dan Pembangunan Regional. Antropologi Indonesia Vol. 29. No. 3. Hal 269-288.

\section{Thesis and Dissertations}

Anindita, A.Dipta. (2006). Memaknai Keberadaban: Studi etnografi Kritis Pemaknaan Bujang Orang Rimba Atas Label dan Stereotip Media Massa. Departemen Ilmu Komunikasi, Universitas Indonesia.

Prasetijo, Adi. (2007). Orang Kubu Mencampok Adat: Etnografi Kehidupan Orang Kubu dalam Tekanan Dominasi Orang Melayu di Jambi.

Rokhdian, Dodi. (2011). Alim Rajo Disembah, Piado Alim Rajo Disanggah Ragam Bentuk Perlawanan Orang Rimba Terhadap Kebijakan Zonasi Taman Nasional Bukit Duabelas (TNBD) Jambi. Departemen Antropologi, Universitas Indonesia.

Sager, Steven. (2008). The Sky is Our Roof, The Earth Our Floor, Orang Rimba Customs, and Religion in Bukit Duabelas region of Jambi. Disertasi.The Australian National University.

Sasmita, Karno. (2009). Etnoekologi Perladangan Orang Rimba, Tesis Sekolah Pascasarjana Program Studi Ilmu Kehutanan Universitas Gadjah Mada, Yogyakarta

Soetomo, Muntholib. (1995).Orang Rimbo: Kajian Struktural-Fungsional Masyarakat Terasing di Makekal. Disertasi Universitas Padjadjaran-Bandung.

\section{Website}

Mendatu, Achmanto. Orang Rimba Menantang Zaman-Mengenal Orang Rimba. http://www.goodreads.com/story/show/2412.

http://www.warsi.or.id 